\title{
The Effect of Job Responsibility, Emotional Intelligence, and Leadership on the Service Quality of Expert Staff for the People's Representative Council of Indonesia
}

\author{
${ }^{1}$ Moch. Aly Taufiq ${ }^{*},{ }^{2}$ R. Madhakomala, ${ }^{3}$ Yetti Supriyati \\ ${ }^{1}$ Postgraduate Program, State University of Jakarta (UNJ), Jakarta-Indonesia \\ ${ }^{2}$ Professor of Faculty of Education, Jakarta State University, State University of Jakarta (UNJ), Indonesia \\ ${ }^{3}$ Professor of Faculty of Mathematics and Natural Sciences, State University of Jakarta (UNJ), Indonesia
}

\begin{abstract}
This study was conducted to determine the effect of work responsibility, emotional intelligence, and leadership on the service quality of the expert staff of the People's Representative Council of Indonesia (DPR RI). This study focused on the service quality of expert staff in the DPR RI using a quantitative approach with Structural Equation Modeling (SEM) method. 325 expert staffs of DPR RI from a total population of 1,725 were involved as the sample of this study. The empirical testing indicates that (1) there is a positive direct effect of job responsibility on service quality; (2) There is a positive direct effect of emotional intelligence on service quality; (3) There is a positive direct effect of leadership on service quality; (4) There is a positive direct effect of job responsibility on leadership; (5) There is a positive effect of emotional intelligence and leadership; (6) there is a significant positive indirect effect of job responsibility on service quality through leadership as the moderating variable; (7) the indirect effect of emotional (X2) on the service quality through leadership is positive and significant.
\end{abstract}

Keywords: Work responsibility, Emotional intelligence, Leadership, Service quality.

\section{Introduction}

Various institutions have assessed the performance of the People's Representative Council of Indonesia (DPR RI) through public satisfaction surveys, including a survey conducted by Charta Politika on 23-26 August 2019 showing the results of unsatisfactory performance of DPR RI. In terms of satisfaction level, people rated $8.8 \%$ very good, $27.5 \%$ good, $29.8 \%$ bad, $13.6 \%$ very bad, and $20.3 \%$ did not answer or did not know. When the respondents were asked about the budgeting function of the DPR RI, $8.5 \%$ of them said it was very good, $25.8 \%$ of them said good, $27.6 \%$ of them said bad, $13.8 \%$ of them said very bad, and $24.3 \%$ of them did not know or did not answer. Alvara Research Center also conducted research related to public satisfaction with the performance of the DPR RI. The results show that the DPR RI is in the 3rd lowest position.

Furthermore, in terms of legislation, the DPR RI has not met the target. In 2015-2019, the People's Representative Council of Indonesia was targeting as many as 246 bills. However, there were only 77 bills passed since July 2019 (Secretariat of the Legislation Body of the DPR RI, 2019). The details are presented in the following table:

Table 1: Target and Realization of the 2015-2019 National Legislation Program

\begin{tabular}{|l|l|l|l|l|l|l|}
\hline Year & $\mathbf{2 0 1 5}$ & $\mathbf{2 0 1 6}$ & $\mathbf{2 0 1 7}$ & $\mathbf{2 0 1 8}$ & $\mathbf{2 0 1 9}$ & Total \\
\hline Target & 40 & 51 & 52 & 49 & 54 & 246 \\
\hline Realization & 18 & 19 & 17 & 15 & 8 & 77 \\
\hline
\end{tabular}


In carrying out their duties, members of the DPR RI are assisted by expert staff. The expert staff of DPR RI is one of the DPR RI subsystems which functions to provide input to members of the DPR RI. Expert staff also functions to assist the DPR RI in preparing material for the discussion of legislation. The expert staff serves members in preparing the academic text of the law to be a bill ready to be proposed.

Levine as quoted (Dwiyanto, 2014) suggested that one important aspect of service quality is job responsibility. It can be said that the higher one's work responsibility, the higher the quality of service provided. M.N. Nasution argued that one of the main dimensions of service quality is performance. A person can be considered qualified if he can meet the standards determined based on the agreed vision and mission (Denny Iskandar, 2005).

According to Goleman (2016), the good and bad of service quality is affected by emotional intelligence. It is supported by a study conducted by Trisnaningsih (2019), concluding that emotional intelligence has a significant and very strong effect on service quality. Moreover, Maukar (2012) suggested that the increase in emotional intelligence, the greater the service.

Amstrong and Baron identified that leadership factors affect service quality. This is reinforced by the findings of Riau (2017) who stated that there is a positive direct effect of leadership on the quality of employee service. Based on the opinions of the experts above, three factors affect service quality, namely job responsibility, emotional intelligence, and leadership.

\section{Theoretical Framework}

According to Luise and Kurtz (1995), "Service Quality refers to the expected perceived quality of service offering. It is the primary determinant of customer satisfaction or dissatisfaction". Meanwhile, according to Mangold and Babakus (1992), "Service Quality in the Outcome of a process in which consumers' expectations for the compared with their perceptions of the service delivered". Zaithami and Bitner (2003) suggested that service quality is "the extend of discrepancy between customer's expectations or desires and their perceptions”. Sricharoenpramong (2018) proposed five dimensions in service quality, namely reliability, responsiveness, assurance, empathy, and tangibles.

Colquitt stated that "job responsibility refers to the nature of the obligations that a person has toward others, generally speaking, the level of responsibility in a job is higher when the number, scope, and importance of the obligatic that job are higher (Colquitt et al., 2011). Dooreward, Van Hootegem, and Huys (2002) divided job responsibility into three important things, namely work preparation, work support, and work control.

According to Goleman (2016), emotional intelligence is an emotional ability which includes the ability to control yourself, to have endurance when facing a problem, to be able to control impulses, to motivate yourself, to be able to regulate mood and to empathize as well as build relationships with others. John D. Mayer, Peter Salovey, and David R. Caruso (2016) defined emotional intelligence as "the ability to perceive and express emotion, assimilate emotion in thought, understand and reason with emotion, and regulate emotion in the self and others..." Meanwhile, according to Howell (2014), emotional intelligence is "the capacity for recognizing our feelings and those of others, for motivating ourselves, and for managing emotions well in ourselves and our relationships.

Michael A. Hogg (2005) suggested that leadership is about dealing with humans and about changing human behavior and attitudes to match the vision of the leader of the group or organization. Therefore, leadership usually relates to a group or organization. Mattone (2013), argued that a successful leader at least has the characteristics such as courage, loyalty, diligence, modesty, honesty, and gratitude.

\section{Materials and Methods}

This study employed the Structural Equation Modeling (SEM) method as the analysis approach. The variables of this study were job responsibility (X1), emotional intelligence (X2), leadership (X3), and service quality (Y). This study involved 325 people out of a total population of 1,710 DPR RI expert staffs 
who served at the DPR RI Office on J1. Jenderal Gatot Subroto Jakarta. The number of the samples was determined using Taro Yamane formula as follows (Riduan \& Akdon, 2006): $\mathbf{n}=\mathbf{N} /\left(\left(\mathbf{N} \mathbf{x} \mathbf{d}^{2}\right)+\mathbf{1}\right)$

The research design is presented in the following figure:

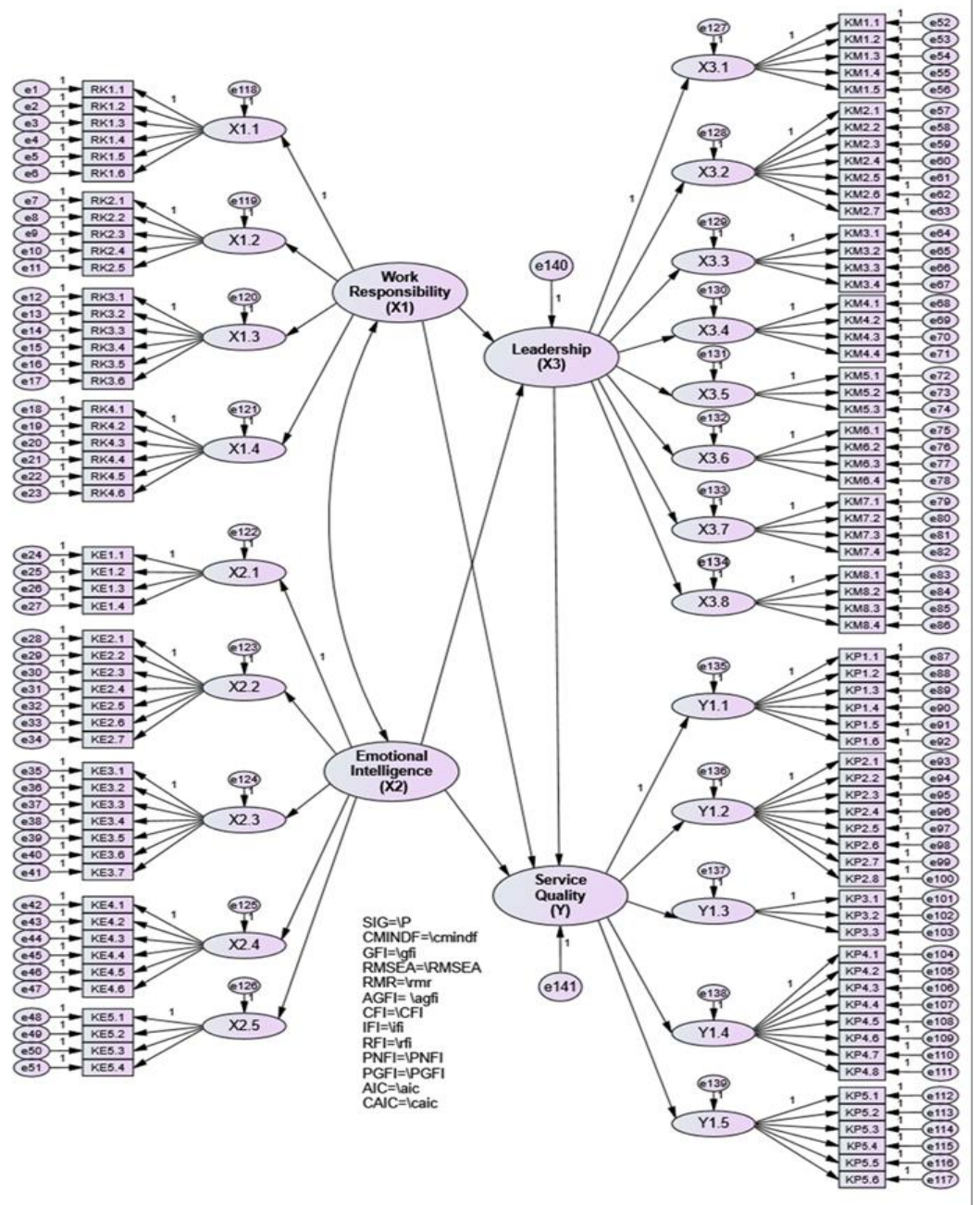

Figure 1; Research Constellation

\section{Result and Discussion}

The following are the descriptive results of the characteristics of the respondents, differentiated based on their gender, educational background, length of work, and the age of the respondents.

Table 2: Characteristics of Respondents Based on Gender

\begin{tabular}{|l|l|l|l|l|l|}
\hline \multicolumn{2}{|c|}{} & Frequency & Percent & Valid Percent & Cumulative Percent \\
\hline \multirow{3}{*}{ Valid } & Male & 281 & 86.5 & 86.5 & 86.5 \\
\cline { 2 - 6 } & Female & 44 & 13.5 & 13.5 & 100.0 \\
\cline { 2 - 6 } & Total & 325 & 100.0 & 100.0 & \\
\hline
\end{tabular}


Table 3: Characteristics of Respondents Based on Educational Background

\begin{tabular}{|l|l|l|l|l|l|}
\hline \multicolumn{2}{|c|}{} & Frequency & Percent & $\begin{array}{l}\text { Valid } \\
\text { Percent }\end{array}$ & $\begin{array}{l}\text { Cumulative } \\
\text { Percent }\end{array}$ \\
\hline \multirow{4}{*}{ Valid } & Diploma/academy & 4 & 1.2 & 1.2 & 1.2 \\
\cline { 2 - 6 } & S1 (Bachelor) & 171 & 52.6 & 52.6 & 53.8 \\
\cline { 2 - 6 } & S2 (Master) & 144 & 44.3 & 44.3 & 98.2 \\
\cline { 2 - 6 } & S3 (Doctoral) & 6 & 1.8 & 1.8 & 100.0 \\
\cline { 2 - 6 } & Total & 325 & 100.0 & 100.0 & \\
\hline
\end{tabular}

Table 4: Characteristics of Respondents Based on Age

\begin{tabular}{|l|l|l|l|l|l|}
\hline \multicolumn{2}{|c|}{} & Frequency & Percent & $\begin{array}{l}\text { Valid } \\
\text { Percent }\end{array}$ & $\begin{array}{l}\text { Cumulative } \\
\text { Percent }\end{array}$ \\
\hline \multirow{3}{*}{ Valid } & $<20$ y.o. & 2 & .6 & .6 & .6 \\
\cline { 2 - 6 } & $21-30$ y.o. & 46 & 14.2 & 14.2 & 14.8 \\
\cline { 2 - 6 } & $31-40$ y.o. & 210 & 64.6 & 64.6 & 79.4 \\
\cline { 2 - 6 } & $41-50$ y.o. & 59 & 18.2 & 18.2 & 97.5 \\
\cline { 2 - 6 } & $>50$ y.o. & 8 & 2.5 & 2.5 & 100.0 \\
\cline { 2 - 6 } & Total & 325 & 100.0 & 100.0 & \\
\hline
\end{tabular}

Table 5: Characteristics of Respondents Based on the Length of Work

\begin{tabular}{|l|l|l|l|l|l|}
\hline \multicolumn{2}{|c|}{} & Frequency & Percent & $\begin{array}{l}\text { Valid } \\
\text { Percent }\end{array}$ & $\begin{array}{l}\text { Cumulative } \\
\text { Percent }\end{array}$ \\
\hline \multirow{3}{*}{ Valid } & $<2$ y.o. & 101 & 31.1 & 31.1 & 31.1 \\
\cline { 2 - 6 } & $2-4$ y.o. & 33 & 10.2 & 10.2 & 41.2 \\
\cline { 2 - 6 } & $4-8$ y.o. & 104 & 32.0 & 32.0 & 73.2 \\
\cline { 2 - 6 } & $8-12$ y.o. & 62 & 19.1 & 19.1 & 92.3 \\
\cline { 2 - 6 } & $>12$ y.o. & 25 & 7.7 & 7.7 & 100.0 \\
\hline & Total & 325 & 100.0 & 100.0 & \\
\hline
\end{tabular}

The direct effect testing on the research model was carried out by looking at the path coefficient value in each research hypothesis path followed by the t-test (C.R: Critical Ratio) to determine the path coefficient value or the value of the effect in the significant category. Meanwhile, the indirect effect test of this study was carried out by looking at the path coefficient value in each research hypothesis path and continued with the Sobel test to determine the path coefficient value or effect value in the significant category. The Sobel formula used was as follows

$$
Z=\frac{a * b}{\sqrt{\mathrm{b}^{2} S_{a}{ }^{2}+a^{2} S_{b}{ }^{2}}}
$$

The test criterion in determining the significance of the indirect effect using the Sobel test was if the $\mathrm{z}$ (Sobel) value is greater than 1.96. 
From the calculation of Structural Equation Modeling, the direct effect of job responsibility (X1) on service quality (Y), the path coefficient value of py1 is 0.306 , and CR ( $\left.\mathrm{t}_{\text {count }}\right)$ is 5.686 . In other words, since the CR (5.686) $\geq 1.96, \mathrm{H}_{1}$ is accepted and $\mathrm{H}_{0}$ is rejected. It can be interpreted that there is a significant positive direct effect from job responsibility (X1) on service quality (Y). The results of the first hypothesis analysis provide the findings that job responsibility (X1) has a positive direct effect on service quality (Y). Thus, better job responsibility might cause service quality to increase, and vice versa. The lower job responsibility might cause service quality to decrease.

The results of the calculation of Structural Equation Modeling related the direct effect of emotional intelligence (X2) on service quality (Y) showed that the path coefficient value of $\mathrm{p}_{\mathrm{y} 2}$ is $\mathbf{0 . 2 9 3}$ and CR ( $\mathrm{t}_{\text {count }}$ ) is 5.316. Since CR $(5.316) \geq 1.96$, the results of the second hypothesis analysis provides findings that emotional intelligence (X2) has a direct positive effect on service quality (Y). In other words, higher emotional intelligence (X2) might lead to an increase in service quality and vice versa. The lower emotional intelligence might lead to a decrease in service quality.

The results of the calculation of Structural Equation Modeling related the direct effect of leadership (X3) on service quality (Y) showed that the path coefficient value of $\mathrm{p}_{\mathrm{y} 2}$ is 0.308 and $\mathrm{CR}\left(\mathrm{t}_{\text {count }}\right)$ is 5.538 . Because CR $(5.538) \geq 1.96$, the third hypothesis analysis provides the findings that leadership (X3) has a positive direct effect on service quality (Y). It can be said that better leadership (X3) might cause an increase in service quality and vice versa. The lower the leadership might cause a decrease in service quality.

The results of the calculation of Structural Equation Modeling related to the direct effect of job responsibility $\left(\mathrm{X}_{1}\right)$ on leadership (X3) showed that the path coefficient value of $\mathrm{p}_{21}$ is 0.309 and $\mathrm{CR}\left(\mathrm{t}_{\text {count }}\right)$ is 5.165. Since CR $(5.165) \geq 1.96$, the fourth hypothesis analysis provides the findings that job responsibility (X1) has a positive direct effect on leadership (X3). Thus, higher job responsibility (X1) might lead to increased leadership (X3) and lower job responsibility (X1) might cause a decrease in leadership (X3).

The results of the calculation of Structural Equation Modeling related to the direct effect of emotional intelligence (X2) on leadership (X3) showed that the path coefficient value of $\mathrm{p}_{32}$ is 0.384 and $\mathrm{CR}$ ( $\mathrm{t}_{\text {count }}$ ) is 6.160. Since CR $(6.160) \geq 1.96$, the fifth hypothesis analysis provides findings that emotional intelligence (X2) has a positive direct effect on leadership (X3). In other words, higher emotional intelligence (X2) might lead to increased leadership (X3) and the lower emotional intelligence (X2) might cause a decrease in leadership (X3.

The constellation of the indirect effect model of job responsibility on service quality through leadership is as follows:

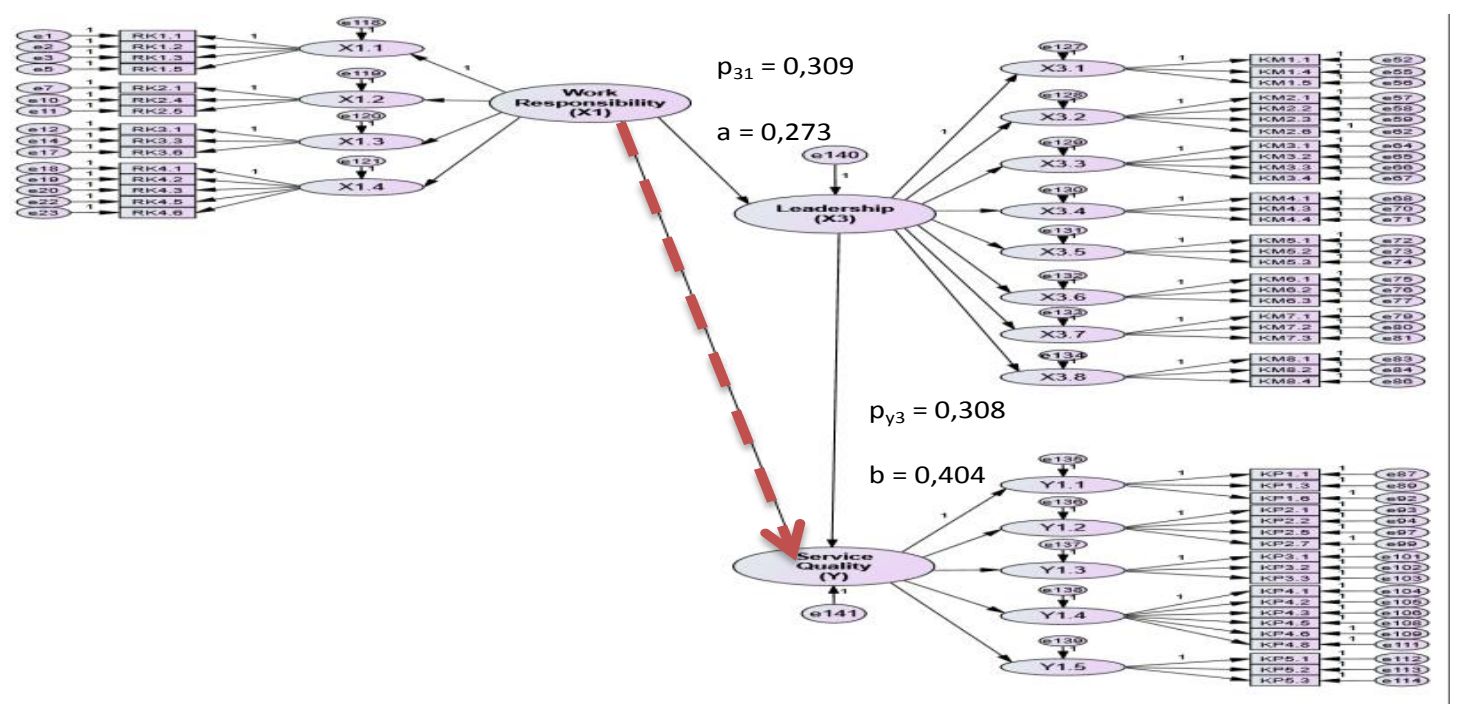

Figure 2: the constellation of indirect effect of X1 on Y through X3 
The path coefficient (mediation) of the indirect effect of job responsibility on service quality through leadership is 0.095 with a $\mathrm{Z}$ value (Sobel test) of 3.357. Since the $\mathrm{Z}$ value (3.357) is greater than 1.96 , it can be concluded that the indirect effect of work responsibility (X1) on service quality (Y) through leadership (X3) is positive and significant. The calculation results of the Sobel test were obtained using the online Sobel test calculator.

The constellation of the indirect effect model of emotional intelligence on service quality through leadership is as follows:

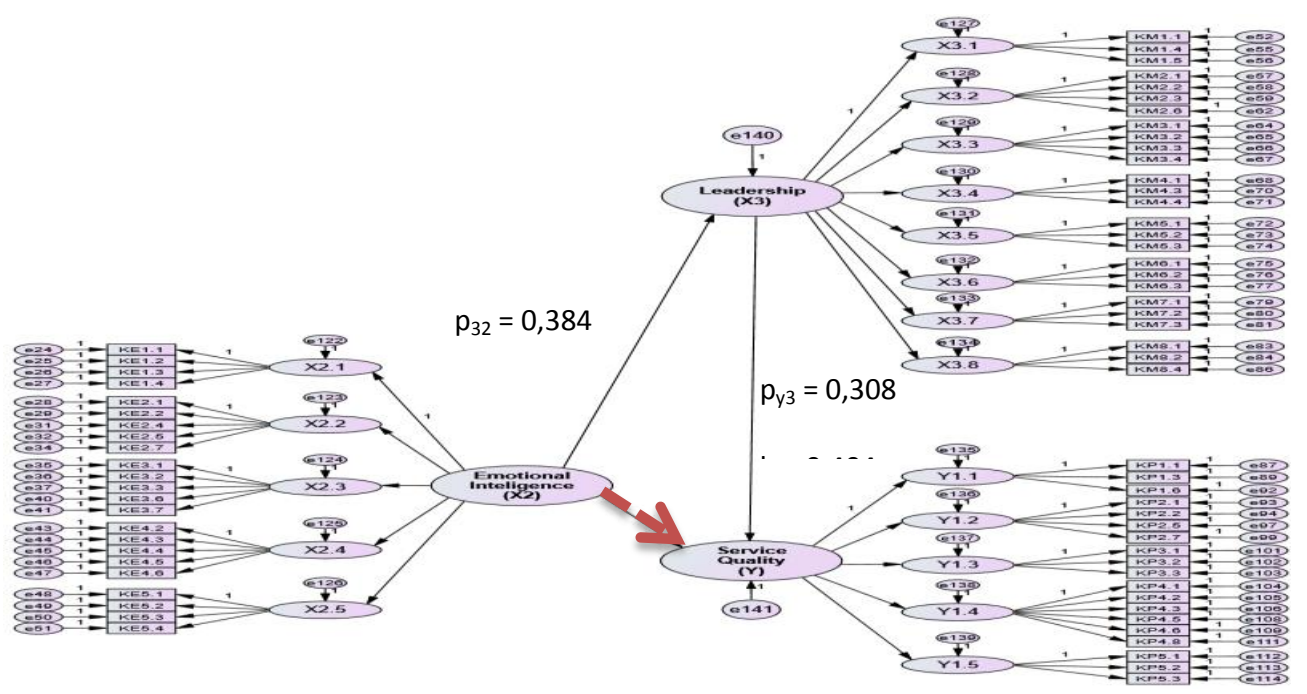

Figure 3: The constellation of the indirect effect of X2 on Y through X3

The path coefficient (mediation) of the indirect effect of emotional intelligence on service quality through leadership is 0.118 with a $\mathrm{z}$ value (Sobel test) of 5.097. Since the $\mathrm{z}$ value (5.097) is greater than 1.96, it can be concluded that the indirect effect of emotional intelligence (X2) on service quality (Y) through leadership (X3) is positive and significant. The calculation results of the Sobel test were obtained using the online Sobel test calculator.

Table 6: Summary of Hypotheses Testing Results

\begin{tabular}{|l|l|l|l|l|}
\hline Direct Effect & Path Coefficient & $\begin{array}{l}\text { (C.R.) } \\
\mathbf{t}_{\text {count }}\end{array}$ & t & Test Decision \\
\hline $\mathrm{X}_{1}$ on $\mathrm{Y}$ & 0.306 & 1.96 & $\begin{array}{l}\mathrm{H}_{0} \text { is rejected, } \mathrm{H}_{1} \text { is accepted. } \\
\text { There is a positive direct effect } \\
\text { of } \mathrm{X}_{1} \text { on } \mathrm{Y}\end{array}$ \\
\hline $\mathrm{X}_{2}$ on $\mathrm{Y}$ & 0.293 & 5.316 & 1.96 & $\begin{array}{l}\mathrm{H}_{0} \text { is rejected, } \mathrm{H}_{1} \text { is accepted. } \\
\text { There is a positive direct effect } \\
\text { of } \mathrm{X}_{2} \text { on } \mathrm{Y}\end{array}$ \\
\hline $\mathrm{X}_{3}$ on $\mathrm{Y}$ & 0.308 & 5.538 & 1.96 & $\begin{array}{l}\mathrm{H}_{0} \text { is rejected, } \mathrm{H}_{1} \text { is accepted. } \\
\text { There is a positive direct effect } \\
\text { of } \mathrm{X}_{3} \text { on } \mathrm{Y}\end{array}$ \\
\hline $\mathrm{X}_{1}$ on $\mathrm{X}_{3}$ & 0.309 & 5.165 & 1.96 & $\begin{array}{l}\mathrm{H}_{0} \text { is rejected, } \mathrm{H}_{1} \text { is accepted. } \\
\text { There is a direct positive effect } \\
\text { of } \mathrm{X}_{1} \text { on } \mathrm{X}_{3}\end{array}$ \\
\hline $\mathrm{X}_{2}$ on $\mathrm{X}_{3}$ & 0.384 & 6.160 & 1.96 & $\begin{array}{l}\mathrm{H}_{0} \text { is rejected, } \mathrm{H}_{1} \text { is accepted. } \\
\text { There is a direct positive effect } \\
\text { of } \mathrm{X}_{2} \text { on } \mathrm{X}_{3}\end{array}$ \\
\hline
\end{tabular}




\begin{tabular}{|l|l|l|l|l|}
\hline Indirect Effect & Path Coefficient & $\mathbf{Z}_{\text {(Sobel Test) }}$ & $\mathbf{Z}_{\text {(Critical Ratio) }}$ & Test Decision \\
\hline $\begin{array}{l}\mathrm{X}_{1} \text { on Y through } \\
\mathrm{X}_{3}\end{array}$ & 0.095 & 3.357 & 1.96 & $\begin{array}{l}\mathrm{H}_{0} \text { is rejected, } \mathrm{H}_{1} \text { is accepted. } \\
\text { There is a positive indirect } \\
\text { effect of } \mathrm{X}_{1} \text { on } \mathrm{Y} \text { through } \mathrm{X}_{3}\end{array}$ \\
\hline $\begin{array}{l}\mathrm{X}_{2} \text { on Y through } \\
\mathrm{X}_{3}\end{array}$ & 0.118 & 5.097 & 1.96 & $\begin{array}{l}\mathrm{H}_{0} \text { is rejected, } \mathrm{H}_{1} \text { is accepted. } \\
\text { There is a positive indirect } \\
\text { effect of } \mathrm{X}_{2} \text { on } \mathrm{Y} \text { through } \mathrm{X}_{3}\end{array}$ \\
\hline
\end{tabular}

\section{Conclusion}

Based on the findings and discussion above, the following conclusions were drawn:

1. Job responsibility (X1) has a positive direct effect on service quality (Y). This can be interpreted that the better job responsibility might cause the service quality to increase and vice versa. The lower work responsibility (X1) might cause a decrease in service quality (Y).

2. Emotional intelligence (X2) has a positive direct effect on service quality (Y). In other words, the higher the emotional intelligence (X) indicating an increase in service quality and vice versa. The lower emotional intelligence might cause a decrease in service quality.

3. Leadership (X3) has a positive direct effect on service quality (Y). In other words, the better the leadership (X3) might cause an increase in service quality and vice versa. The worse the leadership (X3) might cause a decrease in service quality.

4. Job responsibility (X1) has a positive direct effect on leadership (X3). Thus, higher job responsibility (X1) might lead to increased leadership (X3) and lower job responsibility (X1) might cause a decrease in leadership (X3).

5. Emotional intelligence (X2) has a positive direct effect on leadership (X3). Therefore, the higher emotional intelligence (X2) might lead to increased leadership (X3) an the lower emotional intelligence (X2) might cause a decrease in leadership (X3).

6. The indirect effect of job responsibility (X1) on service quality (Y) through leadership (X3) is positive and significant.

7. The indirect effect of emotional intelligence (X2) on service quality (Y) through leadership (X3) is positive and significant.

\section{References}

[1.] Babakus, E, and Mangold, WG (1992), "Adapting The Servquel scal to Hospital Service: an Empirical Investigation” Health service research, Vol 26 (2) February. H. 60.

[2.] Colquitt, Jason A., Lepine, Jeffrey A., \& Wesson, Michael J. (2011). Organizational Behawj. Boston: McGraw-Hill, 146.

[3.] Denny Iskandar, T. (2005). Total Quality Management Dalam Upaya Meningkatkan Mutu Produk, Guna Menunjang Aktivitas Perusahaan. Jurnal Manaiemen Krida Wacana, 5, 165-180.

[4.] Dwiyanto, Agus. (2014). Mewujudkan Good Governance melalui pelayanan public. Yogyakarta: Gajah Mada University Press, 144.

[5.] Dooreward, Hans, Hootegem, Geert Van, \& Huys, Rik. (2002). "Team responsibility structure and team performance". Emerald Journal, Personnel Review, Germany, Vol. 31 No 3, 356-370.

[6.] Goleman, Daniel. (2016). Kecerdasan Emosional, terjemahan T. Hermaya. Jakarta: Gramedia, 17 163.

[7.] Hogg, Michael A. (2005). "Social Identity and Leadership”, dalam The Psychology of leadership New Perspectives and Research: Edited by David M. Messick\& Roderick M. Kramer: London: Lawrence Erlbaum Associates, Publishers, 54-62.

[8.] Howell, Thimothy J. (2014). Daniel Goleman - Emotional, University of Denver University Collage, 3. http://www.tnlds.com/tim/COMM\%204220\%20Howell.T\%20Theorist-Goleman.pdf

[9.] Kouzes, \& Posner, (2008). Tantangan Kepemimpinan, terjemahan Anton Adiwiyoto. Batam: Interaksara, 32-59. 
[10.] Luise Boone dan Kurtz David (1995), “Contemporary Marketing Plus. Eight Edition. (Florida: The Dryden Press, 1995).h.439.

[11.] Mayer, J. D., Caruso, D. R., \& Salovey, P. (2016). The Ability Model of Emotional Intelligence: Principles and Updates. Emotion Review, 8(4), 290-300. https://doi.org/10.1177/1754073916639667

[12.] Mattone, John. (2013). Intelligent Leadership, New York: Amacom, 16-31.

[13.] Riduwan \& Akdon. (2006). Rumus dan data dalam Aplikasi Statistika dama Manajemen, Bandung: Alfabeta, 249.

[14.] Sricharoenpramong, S. (2018). Service quality improvement of ground staff at Don Mueang International Airport. Kasetsart Journal of Social Sciences, 39(1), 15-21. https://doi.org/10.1016/j.kjss.2017.12.001.

[15.] Zaithami, Valarie A, and Bitner, Mary Jo (2003), Service Marketing. Int'l Edition (new York McGraw Hill Inc. h. 19. 